\begin{tabular}{l|lll}
\hline History Article & Received: Maret 2020 & Approved: Agustus 2020 & Published: Agustus 2020 \\
\hline
\end{tabular}

\title{
ANALISIS KOMBINASI PEMBELAJARAN MODUL, E-MODUL, DAN GAYA BELAJAR TERHADAP HASIL BELAJAR BIOLOGI
}

\author{
Anggia Dwi Larasati ${ }^{1}$ Agus Sujarwanta ${ }^{2}$ \\ 1,2 Program Pascasarjana/Magister Pendidikan Biologi/Universitas Muhammadiyah Metro \\ 1E-mail: anggiadwilarasati97@gmail.com²agussujarwanta5@gmail.com
}

\begin{abstract}
Abstrak: Hasil belajar adalah perolehan akhir dari proses pembelajaran. Hasil belajar merupakan batasan yang dimiliki siswa dalam memahami materi. Hasil belajar yang baik dapat mencerminkan gaya belajar yang baik karena mengetahui dan memahami gaya belajar yang terbaik baginya akan membantu siswa belajar sehingga hasil belajarnya akan maksimal. Tujuan penelitian ini adalah untuk mengetahui pengaruh kombinasi modul pembelajaran terhadap hasil belajar, pengaruh gaya belajar terhadap hasil belajar, dan pengaruh kombinasi modul pembelajaran dan gaya belajar terhadap hasil belajar. Teknik yang digunakan untuk mengumpulkan data tentang hasil belajar siswa, tes yang dilakukan adalah tes formatif. Bentuk soal yang digunakan adalah soal pilihan ganda yang disusun dengan penilaian yang mengacu pada standar kompetensi dan kompetensi dasar. Teknik analisis data yang akan digunakan untuk menguji hipotesis dalam penelitian ini adalah menggunakan statistik parametrik inferensial dengan menggunakan teknik analisis klasifikasi dua arah Anova. Sebelum menguji hipotesis, dilakukan uji normalitas dan homogenitas data sebagai prasyarat analisis data.
\end{abstract}

Kata kunci: e-modul, gaya belajar, modul

\begin{abstract}
Learning outcomes are the final acquisition of the learning process. Learning outcomes are the limits owned by students in understanding the material. Good learning outcomes can reflect a good learning style because knowing and understanding the best learning styles for him will help students learn so that the results will be maximal. The purpose of this study is to determine the effect of the combination of learning modules on learning outcomes, the influence of learning styles on learning outcomes, and the effect between the combination of learning modules and learning styles on learning outcomes. The technique used to collect data about student learning outcomes, the tests carried out are formative tests. Forms of the questions used are multiple choice questions compiled with a grid that refers to competency standards and basic competencies. Data analysis technique that will be used to test the hypothesis in this study is to use inferential parametric statistics by using the Anova two way classification analysis technique. Before testing the hypothesis, normality and homogeneity of the data are tested as a prerequisite for data analysis. Based on the research conducted, it can be concluded that the e-modules studied are feasible to be used as one of the reference teaching materials in learning biology in schools.
\end{abstract}

Keywords: e-module, learning style, module

\section{How to Cite}

Larasati, Anggia Dwi, dan Agus Sujarwanta. 2020. Analisis Pembelajaran Modul, e-Modul dan Gaya Belajar terhadap Hasil Belajar Biologi. Biolova 1(2). 67-71. 
Perkembangan zaman yang semakin modern terutama dalam era globalisasi saat ini menuntut adanya sumber daya manusia yang berkualitas tinggi yang berguna untuk bangsa dan negara. Hal utama yang harus ditempuh untuk membekali diri dengan pendidikan adalah belajar positif. Diharapkan melalui pendidikan, khusus ditingkat sekolah menengah memiliki kualitas sumber daya manusia dapat meningkatkan mutu kehidupan. Pendidikan mempunyai peran yang sangat penting dalam meningkatkan sumber daya manusia dan upaya mewujudkan cita-cita bangsa Indonesia dalam mewujudkan kesejahteraan umum dan mencerdaskan kehidupan bangsa. Tantangan dalam bidang pendidikan yang dirasakan selama ini adalah sulitnya meningkatkan mutu pendidikan, sehingga usaha pemerintah dibidang pendidikan selalu diarahkan untuk menyempurnakan sistem pengajaran maupun materi pelajaran ini terlihat dari usaha pemerintah dalam mengadakan perbaikan dan penyempurnaan kurikulum yang didalamnya mencakup isi materi pelajaran, tujuan pembelajaran atau metode-metode dalam mengajar.

Proses belajar pembelajaran merupakan inti dari kegiatan pendidikan di sekolah, salah satu prinsip dalam pendidikan adalah peserta didik secara aktif mengambil dalam kegiatan, karena proses belajar merupakan kegiatan interaksi antara tiga unsur manusia yakni siswa sebagai pihak yang belajar, guru sebagai pihak yang mengajar, dan sumber belajar. Suatu proses pembelajaran dikatakan baik, bila proses tersebut dapat membangkitkan kegiatan belajar yang efektif, sehingga dapat memperoleh hasil belajar yang maksimal. Hasil belajar yang maksimal dapat pula dilihat dari bagaimana gaya belajar siswa dikelas saat proses pembelajaran. Pembelajaran adalah merupakan suatu proses yang membuat orang belajar. Setiap proses pembelajaran tersebut, peran guru bertugas membantu peserta didik agar dapat belajar dengan baik dan mudah. Di samping itu, peserta didik berusaha untuk mencari informasi, memecahkan masalah, dan mengemukakan pendapatnya. Pembelajaran mengandung makna adanya kegiatan belajar dan mengajar, dimana yang mengajar adalah pendidik dan yang belajar adalah peserta didik, yang berorientasi pada pengembangan pengetahuan, sikap, dan keterampilan peserta didik.

Menurut Ghufron

(2012)

menyatakan bahwa Gaya belajar merupakan sebuah pendekatan yang menjelaskan mengenai bagaimana individu belajar atau cara yang ditempuh oleh masing-masing orang untuk berkonsentrasi pada proses, dan menguasai informasi yang sulit dan baru melalui persepsi yang membedaka orang yang satu dengan yang lain. Menurut Deporter dan Hernacki (2011) gaya belajar merupakan suatu kombinasi dari bagaimana seseorang menyerap, dan kemudian mengatur serta mengolah informasi. Berdasarkan pendapat sebelumnya, gaya belajar setiap individu berbeda-beda untuk berkosentrasi pada proses belajar mengajar dalam menguasai informasi yang sulit melalui persepsi. Kesimpulan dari kutipan di atas bahwa gaya belajar setiap orang berbeda-beda, sesuai kebiasaan orang tersebut dalam menyerap, mengatur, dan mengolah informasi.

Mempelajari suatu materi pelajaran merupakan salah satu pekerjaan yang sulit dilakukan, tidak menyenangkan dan membosankan, itulah pernyataan yang sering terdengar dari kebanyakan siswa serta berdasarkan kenyataan yang ada pada siswa dari tingkat Sekolah Dasar sampai tingkat Perguruan Tinggi. Hal ini dapat dibuktikan dengan kurangnya tanggapan dan perhatian siswa ketika guru atau dosen sedang menyampaikan materi pelajaran di dalam kelas. Sering terlihat sebagian besar siswa hanya datang, duduk, dengar, dan diam. Apabila keadaan seperti ini terus berlangsung maka belajar mengajar dilakukan dengan secara searah. Padahal dalam proses belajar mengajar di dalam 
kelas diperlukan interaksi antara guru dan siswa. Interaksi antara guru dan siswa yaitu guru menyampaikan materi pelajaran dan siswa menanggapi apa yang disampaikan oleh guru. Interaksi antara guru dan siswa yaitu sesama siswa saling berdiskusi guna menanggapi permasalahan yang muncul dari proses belajar mengajar tersebut.

Pada saat seseorang belajar, maka ia mengikut sertakan seluruh keberadaan dirinya, hal ini berarti bahwa pada saat proses belajar itu berlangsung, bukan saja otak yang bekerja tetapi juga perasaan pada saat seseorang sedang belajar. Hal inilah yang menyebabkan siswa MAN 1 Metro mampu berkonsentrasi belajar. Dalam waktu yang lama, mereka akan mudah merasa lelah sehingga tidak mampu belajar secara optimal. Selain itu juga, siswa MAN 1 Metro Jepara belum dapat mengenal gaya belajar masing-masing, sehingga belajar siswa menjadi kurang optimal. Akibatnya hasil yang dicapai oleh siswa menjadi rendah atau tidak memuaskan. Oleh sebab itu, seorang siswa MAN 1 Metro perlu mengenal gaya belajar mereka supaya dapat memaksimalkan konsentrasi dalam belajar biologi, sehingga siswa dapat menggali materi lebih dalam.

Hasil belajar merupakan perolehan akhir dari proses pembelajaran. Hasil belajar adalah batasan yang dimiliki oleh peserta didik dalam pemahaman materi. Hasil belajar yang baik dapat mencermikan gaya belajar yang baik karena dengan mengetahui dan memahami gaya belajar yang terbaik bagi dirinya akan membantu siswa dalam belajar sehingga hasilnya akan maksimal. Banyak faktor yang mempengaruhi hasil belajar di dalam kelas, sehingga ini menjadi tugas pendidik untuk meningkatkan hasil belajar peserta didik dengan mengetahui gaya belajar peserta didik. Selain itu berdasarkan observasi pada mata pelajaran akuntansi di MAN 1 Metro, terdapat berbagai gaya belajar siswa diantaranya ada yang lebih mengerti ketika guru menjelaskan dengan cara mencatat di papan tulis, berdiskusi, dan memberikan contoh soal terlebih dahulu, sebagian ada yang suka dengan keributan dan sebagian tidak suka dengan keributan ada yang mengerjakan tugas dengan teliti dan ada yang tidak teliti, ada yang belajar sambil berjalan, ada yang tidak dapat duduk diam, dan ada yang suka gerak-gerakan badan.

Berdasarkan prasurvei didapatkan data mengenai hasil belajar di MAN 1 Metro pada materi Plantae terdapat 15 peserta didik yang nilainya belum mencapai KKM. Data prasurvei hasil belajar Biologi materi Sistem Respirasi seperti pada Tabel 1.

\begin{tabular}{|c|c|c|c|c|}
\hline Tabel & \multicolumn{2}{|c|}{$\begin{array}{l}\text { 1. Data } \\
\text { Belajar } \\
\text { Sistem Rest }\end{array}$} & $\begin{array}{l}\text { Prasurvei } \\
\text { Biologi }\end{array}$ & $\begin{array}{r}\text { Hasil } \\
\text { Materi }\end{array}$ \\
\hline No & Nilai & Kriteria & Jumlah & $\%$ \\
\hline 1 & $\geq 75$ & $\begin{array}{c}\text { Sudah } \\
\text { mencapai } \\
\text { KKM }\end{array}$ & 19 & 48 \\
\hline 2 & $<75$ & $\begin{array}{c}\text { Belum } \\
\text { mencapai } \\
\text { KKM }\end{array}$ & 20 & 52 \\
\hline & & & 39 & 100 \\
\hline
\end{tabular}

Tabel 1. Menunjukkan data bahwa hasil belajar pada materi vertebrata terdapat peserta didik yang nilainya belum mencapai KKM (Kriteria Ketentuan Minimal) yaitu 20 orang dari 39 peserta didik. Hal ini menunjukkan hasil belajar peserta didik secara klarifikasi belum tuntas atau masih rendah. Tuntas dalam belajar secara klasifikasi jika $85 \%$ atau lebih dari jumlah peserta didik seluruhnya telah tuntas belajar, dalam hal ini telah mencapai KKM (Damayanti, 2016:224). Sulitnya memahami materi dalam bahan ajar mempengaruhi hasil belajar peserta didik, sehingga pencapaian tujuan pembelajaran belum maksimal.

Berdasarkan penjelasan mengenai hasil belajar dapat dilihat peserta didik mempunyai gaya belajar yang berbedabeda. Demi kesuksesan belajar, gaya belajar yang positif itu haruslah ada dan kuat dari dalam diri peserta didik. Sehingga gaya belajar penting bagi siswa untuk ditingkatkan, karena siswa akan menjadi sadar bahwa ia harus mencapai tujuan dan hasil belajarnya yang maksimal. Untuk itu 
peneliti tertarik meneliti masalah "Pengaruh Kombinasi Pembelajaran Modul dan Gaya Belajar Terhadap Hasil Belajar Biologi Siswa Kelas XI".

METODE

Metode yang digunakan dalam artikel ini adalah studi dokumentasi mengkaji beberapa artikel yang berhubungan dengan modul, e-modul, dan gaya belajar.

\section{HASIL DAN PEMBAHASAN}

Berdasarkan hasil wawancara yang dilakukaan, maka dilakukannya analisis pentingnya kombinasi modul dan emodul dalam proses pembelajaran khususnya mata pelajaran biologi, yaitu sebagai berikut: 1) Diperlukannya bahan ajar yang dapat menunjang kegiatan proses pembelajaran peserta didik dan guru di kelas, 2) perlunya bahan ajar e-modul yang sesuai dengan perkembangan ilmu dan teknologi modern, 3) penggunaan e-modul sudah berkemajuan, di mana dalam penggunaanya nanti lebih memudahkan peserta didik karena dapat di simpan dalam gadget maupun laptop, 4) e-modul nantinya diharapkan dapat memenuhi kebutuhan sekolah dalam proses pembelajaran sebagai media penunjang yang memiliki teknologi berkemajuan.

Berdasarkan analisis kebutuhan hampir seluruh responden (peserta didik) menyukai modul atau e-modul. Namun, peserta didik lebih tertarik dengan emodul. Alasan terbanyak responden adalah belajar menggunakan handpone atau alat elektronik membuat mereka tertarik. Hal ini sesuai dengan pernyataan Seperti yang dikemukakan oleh Fausih (2015:4) menyatakan bahwa karakteristik modul di atas merupakan karakteristik dari modul cetak, namun perincian karakteristik tersebut dapat diaplikasikan dalam $e$ Modul. Pada dasarnya sebuah e-Modul memiliki karakteristik dapat dipelajari di manapundan kapanpun oleh siswa, siswa tidak bergantung pada orang lain (self instructional), $\quad e$-Modul memberikan kesempatan pada siswa untuk aktif dalam proses kegiatan belajar mengajar.

Modul Elektronik terbukti efektif digunakan sebagai alternatif bahan belajar mandiri maupun bahan belajar konvensional. Modul yang disusun secara sistematis dengan memperhatikan pengorganisasian materi pelajaran dapat digunakan sesuai gaya dan kecepatan belajar masing-masing pengguna. Dengan perkembangan teknologi informasi yang dapat diaplikasikan dalam kegiatan pembelajaran, banyak cara yang dapat digunakan untuk mengubah penyajian bahan belajar ke dalam format elektronik atau digital. Penyajian bahan belajar dalam bentuk elektronik ini tentunya akan menjadi lebih menarik dan memberikan berbagai kemudahan. Keberadaan media pembelajaran ini pada akhirnya dapat menunjang dan melengkapi peran guru sebagai satu-satunya sumber informasi bagi peserta didik. Kembali lagi dalam pengertian merupakan salah satu jenis media pembelajaran berbentuk cetak.

\section{KESIMPULAN}

Berdasarkan penjabaran yang telah dijelaskan, dapat disimpulkan bahwa emodul lebih baik untuk digunakan atau layak untuk digunakan pada proses pembelajaran peserta didik dan guru.

\section{SARAN}

Saran yang dapat diberikan dari penelitian adalah sebagai berikut: 1) Penelitian sebaiknya dibuat jadwal target penyelesaian media secara terperinci untuk setiap harinya. Hal ini dapat menghindari kesalahan yang timbul akibat pembuatan produk yang terburu-buru. 2) Penelitian pengembangan selanjutnya, pembuatan media sebaiknya dikerjakan langsung oleh peneliti sehingga diperoleh hasil yang sesuai dengan keinginan peneliti. 3) emodul yang telah dihasilkan dapat diuji coba lagi pada beberapa sekolah dengan kelompok yang lebih besar agar produk yang dihasilkan dapat lebih representatif. 


\section{DAFTAR RUJUKAN}

Abdullah, Ghufron. 2012. Upaya Perguruan Tinggi dalam Mempersiapkan Lulusan Berdaya Saing pada Era Globalisasi. (http://ejurnal.upgrismg.ac.id/index.php/civ is/article/download/601/551) diakses tanggal 22 Oktobr 2019.

Depoter Bobbi dan Hernacki Mike, 2011. Quantum Learning. Jakarta : KAIFA.

Fausih Moh, Danang T. 2015. Pengembangan Media E-Modul Mata Pelajaran Produktif Pokok Bahasan "Instalasi Jaringan LAN (Local Area Network) Untuk Siswa Kelas XI Jurusan Teknik Komputer Jaringan di SMK Negeri 1 Labang Bangkalan Madura. Vol 01. No 01. 2015. Teknologi Pendidikan, Fakultas Ilmu Pendidikan, Universitas Negeri Semarang.

Margono. 2010. Metode Penelitian Pendidikan. Jakarta: Rineka Cipta.

Nanang. 2011. Metode Penelitian Kuantitatif (Analisis Isi dan Analisis Data Sekunder). Jakarta: Raja Grafindo Persada.

Sudjana,Nana dan Rivai. 2009. Dasar-

Dasar Proses Mengajar. Bandung: Sinar Baru Algesindo.

Sugiyono. 2015. Metode Penelitian dan

Pengembangan Research and Development. Bandung: Alfabeta. 